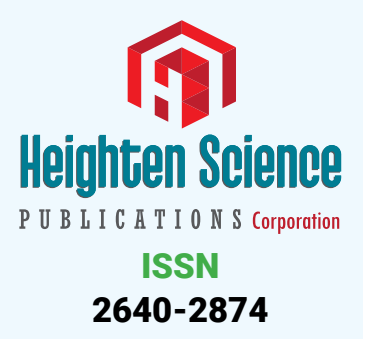

*Address for Correspondence: Ding Dai, MD., PhD. Department of Pathology and Laboratory Medicine, Brody School of Medicine at East Carolina University, 600 Moye Blvd, Greenville, NC 27834, NC, USA, Tel: 252-847-4495; Email: daid14@ecu.edu

Submitted: 10 January 2019

Approved: 28 January 2019

Published: 29 January 2019

Copyright: @ 2019 Dai D, et al. This is an open access article distributed under the Creative Commons Attribution License, which permits unrestricted use, distribution, and reproduction in any medium, provided the original work is properly cited

Keywords: Inflammatory myofibroblastic tumor; Prostate

Check for updates
Case Report

\section{Prostatic inflammatory myofibroblastic tumor: 2-case report with literature review}

\author{
Ding Dai ${ }^{1 * \#, ~ Q i ~ C a i " \# ~ a n d ~ A n n ~ S u t t o n ~}{ }^{1}$ \\ ${ }^{1}$ Department of Pathology and Laboratory Medicine, Brody School of Medicine at East Carolina \\ University, USA \\ ${ }^{2}$ Department of Pathology at UT Southwestern, Dallas, TX, USA \\ "Both authors equally contribute to the manuscript
}

\section{Abstract}

Inflammatory myofibroblastic tumor is rarely seen in the prostate. Most of prostatic tumors are benign. However, local aggressively invading the adjacent organs and recurrence are frequent. Rarely, the malignant transformation and metastasis occurs, especially in elderly patient. The definitive diagnosis in a small biopsy is challenging. The correct diagnosis preoperatively will help to avoid unnecessary radical prostatectomy. Interval follow up is recommended. Here we reported two cases of prostatic inflammatory myofibroblastic tumor with literature review.

\section{Introduction}

Inflammatory myofibroblastic tumor (IMT) is defined as a neoplasm with the morphologic character of proliferating spindle cells admixed with variable amounts of a lymphoplasmacytic infiltrate according to WHO classification. In the past, various names have been used for this tumor, such as "inflammatory pseudotumor" $[1,2]$, "atypical fibromyxoid tumor of the prostate"[3] "pseudosarcomatous fibromyxoid tumor of the prostate" [4-6] or inflammatory fibrosarcoma [7]. It primarily occurs in soft tissue and viscera in children and young adults. The mean age at diagnosis is 10 years and most frequently in the first three decades of life with slight female predominance. It is rarely seen in the prostate. IMT in the prostate was first reported by Hafiz and named as atypical fibromyxoid tumor [3]. The tumor was composed of spindle cells embedded in edematous and myxoid stromal background. The tumor cells were negative for S100 and myoglobulin. Electron microscopy demonstrated the fibroblastic origin of the tumor cells. In this study, the term "atypical fibromyxoid tumor", "inflammatory myofibroblastic tumor" and "inflammatory pseudotumor", "pseudosarcomatous fibromyxoid tumor" were used for literature search. So far, there are dozen cases reported in English literatures. Here we reported 2 cases encountered over last 25 years in our institution.

\section{Case Report}

\section{Case 1}

53-year-old male had a borderline increase of prostate specific antigen (PSA) ranging from $4.0-4.2 \mathrm{ng} / \mathrm{ml}$ over two and half years. Prostate core needle biopsy showed adenocarcinoma with Gleason score $6(3+3)$. Radical prostatectomy was performed 2 months after initial diagnosis. During the surgery, a nodular median lobe was removed separately which was round measuring $2.7 \times 2.1 \times 1.7 \mathrm{~cm}$. The cut surface of the nodule 
was white-tan, homogeneous and fleshy. Microscopic examination revealed prostate adenocarcinoma with Gleason score of $7(3+4), 5 \%$ of tissue involved at each side. Perineural invasion was present. No lymphovascular invasion was identified. Apex and bladder base of the prostate gland and seminal vesicles were uninvolved. The prostate tumor was staged as pT2c, pN0. The nodular median lobe showed fascicles of spindled cells in a loose edematous myxoid stroma arranged in haphazard pattern similar to fibroblasts in tissue culture. The spindle cells have abundant eosinophilic cytoplasm, slender spindle nuclei with tapered end or plump spindle nuclei with blunt ends, and inconspicuous nucleoli. No atypia is present. There were many hyalinized, thick-walled blood vessels. Abundant focal clusters of small mature lymphocytes were present in the stroma. Rare mitotic figures were seen. No prostatic glands were found in the nodular tumor. Immunohistochemical stains of desmin, vimentin, CD34, ALK and S100 were performed. The spindled cells showed diffuse and strong cytoplasmic positivity for desmin, focal positivity for vimentin and CD34. The tumor cells were negative for ALK and S100. The patient was treated supportively postoperation and followed up for three years. No recurrence or metastasis was observed.

\section{Case 2}

76-year-old male presented to emergency department with difficult voiding, dysuria and worsening gross hematuria for several days. CT scan demonstrated a diffusely enlarged prostate and measures up to $10 \mathrm{~cm}$ in diameter. No discrete separate mass was identified. Suprapubic prostatectomy was performed. Two day of uneventful postsurgery course, the patient was discharged. Gross examination showed an enlarged prostate with a weight of 358 grams, measuring $11.5 \times 11.5 \times 6.0 \mathrm{~cm}$. On cut surface, the prostate displayed a white-tan and lobular appearance. Microscopic examination showed the prostate was replaced by diffuse spindle cell lesion. The spindle cells form intercepting short fascicles, some with smooth muscle and fibroblastic differentiation. The spindle cells have plump, spindled nucleus with fine granular chromatin. Some spindle cells have small inconspicuous nucleolus. Scattered lymphocytes and occasional myxoid area are also seen. Scattered thick-walled blood vessels are present. No necrosis was identified. Rare mitosis was present. Ki-67 index showed very low proliferation. No atypical mitosis was identified. The tumor cells were positive for smooth muscle actin and desmin; and negative for S100 and ALK-1. Three-year follow up has not shown any recurrence.

\section{Results}

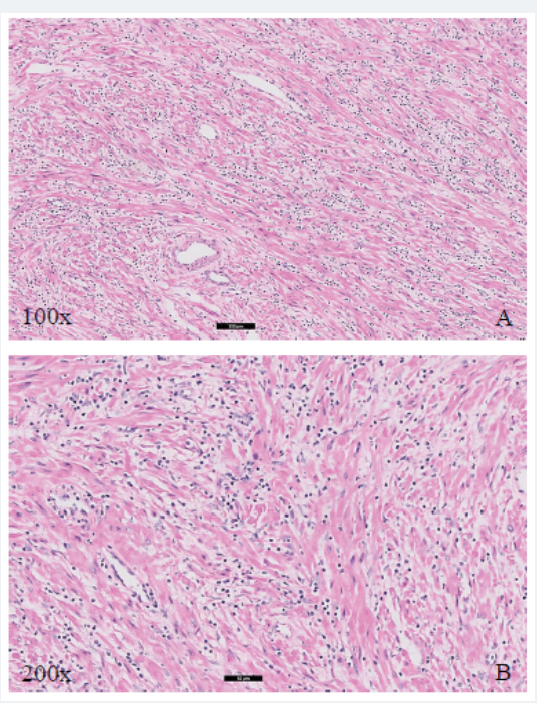

Figure 1: Histopathologic findings (H\&E) in case 1 show spindle cell proliferation in the myxoid stroma with lymphocytic inflammatory infiltration. A $100 \mathrm{X}$ and B. 200X. 


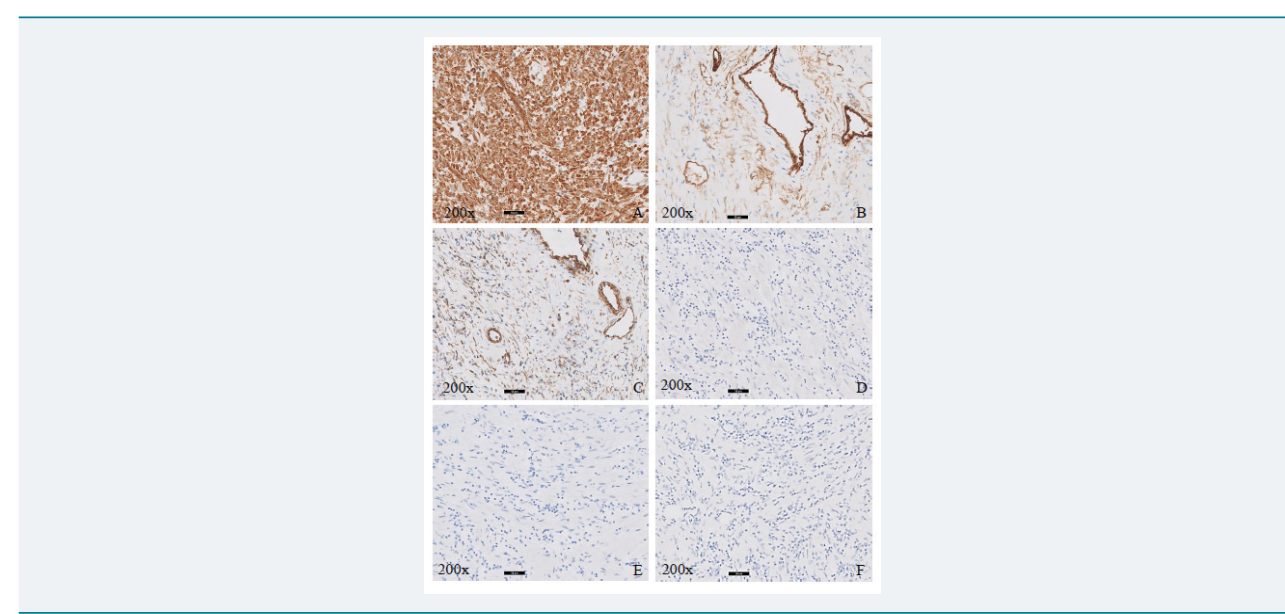

Figure 2: Immunohistochemical stains for case 1, 200X. A. Desmin, B. CD34, C. Vimentin, D. S100, E. Pancytokeratin, F. ALK-1.

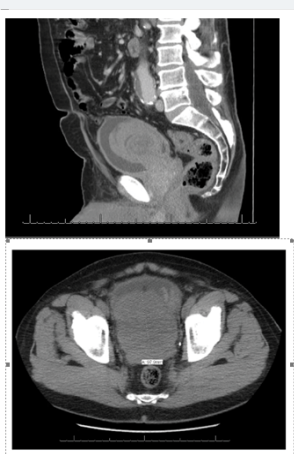

Figure 3: CT image showed enlarged heterogenous prostate gland

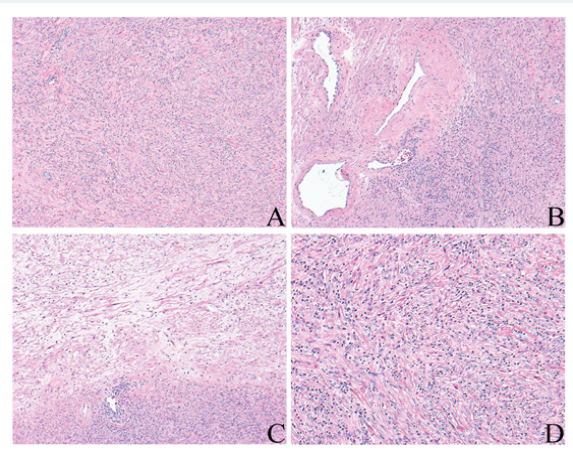

Figure 4: Histopathologic findings (H\&E) in case 2 showed A. spindle cell proliferations with lymphocytic inflammatory infiltration, 100X; B. Thick-walled blood vessels, 100X; C. Myxoid area, 100X and D. Infiltrating lymphocytes, 200X.

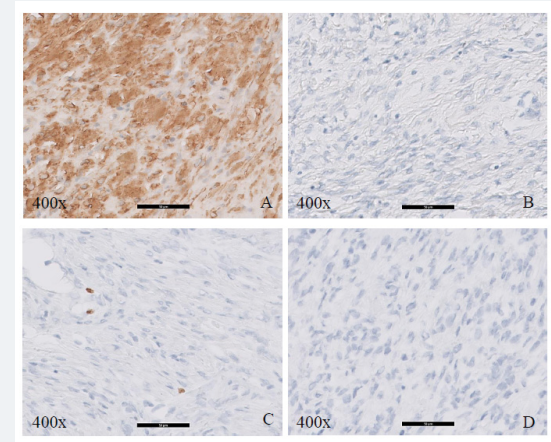

Figure 5: Immunohistochemical stains for case 2, 200X. A. Desmin; B. S100; C. Ki-67, and D. ALK-1. 


\section{Discussion and Conclusion}

IMT can occur in any part of the body at any age with the most common sites in lung and mesentery [8]. IMT is frequently seen in urinary tract. However, prostatic IMT is rarely observed. A literature review was performed. So far, there are only dozen cases reported in the prostate gland (Table 1). The prostatic IMT occurs in the patients between 22 to 80 years old with median of 51 years. The patients with prostatic IMT presented with acute urinary retention, painless hematuria or dysuria (Table 1). Some patients had elevated PSA ranging $5.02-17.1 \mathrm{ng} / \mathrm{ml}$. On physical exam, a palpable soft mass was identified. Imaging study demonstrated a solid or solid-cystic mass with heterogeneous appearance. Gross examination showed that prostatic IMT was lobulated, soft, tan mass [3]. 10 out of 11 patients followed a benign course and symptoms relieved after resection although some with local recurrence, even multiple recurrences. Extremely rare malignant transformation was noticed by long term of follow up. Reported risk factors for prostatic IMT included smoke, previous instrumentation and surgery [9].

IMT is considered as benign tumor with local recurrence but rarely metastases to the distant locations. Based on new WHO classification, metastasis occurs in $<2 \%$ cases. The prostatic IMT can grow rapidly and locally aggressive, invading into the adjacent organs such as the bladder [10]. One reviewed case with local recurrence extending into urinary bladder after two TURP, which resulted in the radical cystoprostatectomy [11]. Due to rarity of case, the rate of malignant transformation in prostatic IMT is unknown. Liu et al., reported one case of 89-year-old patient [12], who had recurrence with malignant transformation and distant metastases in lung and pelvic lymph nodes in 24 months after initial transurethral resection of the prostate (TURP). Repeated review of initial resection did not identify any cytologic atypia. In addition, histopathologic features do not reliably predict the prognosis and they do not correlate with clinical behavior as well. Therefore, close follow up after procedure is very essential, especially in elderly patient.

\begin{tabular}{|c|c|c|c|c|c|c|c|}
\hline & $\begin{array}{l}\text { First author and } \\
\text { reference }\end{array}$ & $\begin{array}{c}\text { Age } \\
\text { (years) }\end{array}$ & $\begin{array}{l}\text { Presenting } \\
\text { symptoms }\end{array}$ & $\begin{array}{l}\text { Surgical } \\
\text { treatment }\end{array}$ & $\begin{array}{l}\text { Follow-up at } \\
\text { time of report }\end{array}$ & IHC** & $\begin{array}{l}\text { PSA } \\
(\mathrm{ng} / \\
\mathrm{ml})\end{array}$ \\
\hline 1 & $\begin{array}{c}\text { Hafiz MA. (US) } \\
{[3]}\end{array}$ & 56 & $\begin{array}{c}\text { nocutria, poor urinary } \\
\text { stream, hesitancy }\end{array}$ & Cystoprostatectomy & $\begin{array}{l}1.5 \text { year - no } \\
\text { recurrence }\end{array}$ & S100, myoglobin: - & $N A^{\star \star \star}$ \\
\hline 2 & RO JY. (US) [4] & 22 & painless hemauria & TURP* & 6 years & $\begin{array}{c}\text { S100, desmin, } \\
\text { AE1/3, myoglobin: - }\end{array}$ & NA \\
\hline 3 & $\begin{array}{l}\text { Toksoz S. } \\
\text { (Turkey) [6] }\end{array}$ & 70 & $\begin{array}{l}\text { Nocturia, urgency } \\
\text { and difficulty in } \\
\text { voiding }\end{array}$ & Prostatectomy & $\begin{array}{l}2 \text { years - no } \\
\text { recurence }\end{array}$ & $\begin{array}{c}\text { Actin: + } \\
\text { Vim, CD34: - }\end{array}$ & 5.02 \\
\hline 4 & $\begin{array}{c}\text { Atis G. (Tuekey) } \\
\text { [9] }\end{array}$ & 61 & $\begin{array}{l}\text { infravesical } \\
\text { obstruction }\end{array}$ & TURP & $\begin{array}{l}1 \text { year - no } \\
\text { malignancy }\end{array}$ & $\begin{array}{l}\text { Vim: }+, A E 1 / 3 \\
\text { CD34: } \\
\text { Ki }<1 \%\end{array}$ & 1.73 \\
\hline 5 & $\begin{array}{c}\text { Jensen JB. } \\
\text { (Denmark) [10] }\end{array}$ & 43 & gross hematuria & TURP $x 6$ & $\begin{array}{l}4 \text { years - no } \\
\text { symptom }\end{array}$ & $\begin{array}{l}\text { Vim, desmin, } \\
\text { actin: + } \\
\text { AE13, S100, } \\
\text { myoglobin: - } \\
\text { Ki67: low }\end{array}$ & 17.1 \\
\hline 6 & $\begin{array}{l}\text { Zhang } \mathrm{H} . \\
\text { (China) [11] }\end{array}$ & 62 & Dysuria & TURP & $\begin{array}{l}2 \text { years }- \text { no } \\
\text { recurrence }\end{array}$ & $\begin{array}{c}\text { Desmin, CD117: + } \\
\text { AE1/3, myogenin: } \\
+/- \\
\text { S100, CD34, DOG- } \\
\text { 1: - }\end{array}$ & 2.3 \\
\hline 7 & $\begin{array}{c}\text { Liu C. } \\
\text { (China) (12) }\end{array}$ & 80 & $\begin{array}{l}\text { acute urinary } \\
\text { retention }\end{array}$ & Prostatectomy & $\begin{array}{l}\mathrm{IMT} . \\
\text { metastasis in } \\
2 \text { years }\end{array}$ & $\begin{array}{l}\text { Actin, desmin, } \\
\text { vim: }+ \\
\text { CD34, S100, CD17: - }\end{array}$ & 5.8 \\
\hline 8 & $\begin{array}{c}\text { Kuramoto } \\
\text { (Japaneses-[24] }\end{array}$ & 42 & $\begin{array}{c}\text { Dysuria and } \\
\text { hematospermia }\end{array}$ & TURP & $\begin{array}{c}5 \text { months - no } \\
\text { recurrence }\end{array}$ & NA & NA \\
\hline \multicolumn{8}{|c|}{$\begin{array}{l}\text { *TURP: Transurethral resection of the prostate } \\
\star \star \text { IHC: Immunohistochemical stain } \\
\star \star \star N A: \text { Not applicable }\end{array}$} \\
\hline
\end{tabular}


Immunophenotype of IMT is not very specific and helpful in facilitating the diagnosis. Most of tumors are positive for actin, desmin, vimentin, and some showing positivity for low molecular weight cytokeratin (CK8/18, CAM 5.2) and pancytokeratin (AE1/3). CD34 staining is variably and focally positive [13]. The tumor cells are negative for myoglobin and S100. In our reported two cases, the tumor cells show diffuse strong positivity for desmin, focal and weak positivity for vimentin and CD34, and negative for S100 and pancytokeratin. Clonal anaplastic lymphoma kinase ALK gene rearrangement can occurs in $50 \%$ of the IMT, which is seen more in children or young adults, and uncommon in adults $>40$ years old. ALK-receptor tyrosine kinase gene located at $2 \mathrm{p} 23$ locus. Recent study discovered that multiple gene rearrangement was identified in IMT such as $A L K, R O S 1, P D G F R B$, and RET. ALK gene rearrangement is the predominant marker [14]. There are cytoplasmic and nuclear membranous staining patterns of ALK1 depend on fusion partners. Fluorescence in situ hybridization (FISH) is gold standard for ALK positivity [15]. There was only $72 \%$ consistency between IHC and FISH results in urinary tract IMT. $50 \%$ of blader IMT demonstrated ALK positivity [12]. So far, rare data of ALK rearrangement in prostatic IMT were available because all reviewed cases (Table 1) are lack of ALK studies. We performed immunohistochemical stain of ALK-1 in our two cases, and both showed ALK-1 negativity. Likewise, Antonescu reported that there was $90 \%$ of negative gene rearrangement IMT present in adult [14]. Further studies are needed to clarify the molecular feature of ALK rearrangement in prostatic IMT. In addition, Montgomery reported that recurrence and metastasis were noted in negative ALK IMTs in urinary tract [13]. However, two ALK negative cases which we reported here were followed up for consecutively 3 years. No recurrence or metastasis was identified.

Radiological feature of IMT in different locations was reported by Cantera [16]. In general, IMT showed a solid and well defined mass. It displayed a homogenous or heterogenous pattern with low intensity on T2 weighted CT imagines. Our reported case 1 in this study showed that a well circumscribed enlarged prostate gland with heterogenous pattern and local low intensity on CT (Figure 3). However, data of magnetic resonance imaging (MRI) analysis were limited. Further MRI study on IMT needs to be investigated.

There are several differential diagnoses present. Postoperative spindle cell nodule (PSCN) usually occurs weeks to months after surgical intervention. It used to be considered as a major differential diagnosis when making the diagnosis of IMT. Morphologically, the both are similar. Postoperative spindle cell nodules are showing more cellular and compact arrangement of the spindle cells. They tend to contain fewer inflammatory cells and the vascular proliferation in the stroma comparison with IMT [17]. The mitotic figures are high up to 25 per 10 high power fields. However, the immunophenotypic features of PSCN are exactly same as those in IMT. The only difference of these two tumors is whether patients have prior operative procedure. Because ALK rearrangement was also found in the PSCN of the bladder [18], few authors have considered PSCN as a subtype of IMT. They divide IMT into two different subtypes based on patients with or without history of prior procedure $[13,19]$. In our reported cases, one of patients had no history of prior procedure and the other one had prostatic biopsy 4 months ago. In addition, benign prostatic stromal hyperplasia is another IMT mimic. Stromal nodule in benign prostate hyperplasia is well demarcated, showing embryonal-mesenchymal fibroblastic, fibromuscular or smooth muscular differentiation. The spindle cells are positive for S100 and neuron specific enolase [20]. If there is fibroblastic differentiation, the spindle cells are positive for vimentin. However, the positivity of desmin and smooth muscle actin can be seen if the tumor with muscular differentiation. Other common differential diagnoses of spindle cell neoplasms include leiomyosarcoma, sarcomatoid urothelial carcinoma, and rhabdomyosarcoma [21,22]. Cytologic atypia are seen in all above mentioned sarcomas. It also needs to rule out stromal reaction in response to invasive carcinoma, and pseudosarcomatous stroma reaction with primary or metastatic carcinoma [23]. 
The correct diagnosis preoperatively is very important, which helps avoid unnecessary radical prostatectomy. However, the rarity poses a challenging on the initial diagnosis, especially on a small biopsy. Awareness of this rare entity and being cautious on biopsy will be helpful.

\section{Statement}

The presented investigations and the publication of data comply with ethical rules of East Carolina University and general rules of experimentation with humans.

\section{References}

1. Pérez García FJ, Pinto Blázquez J, Gutiérrez García R, Lanzas Prieto JM, et al. Inflammatory prostatic pseudotumor (fibromyxoid pseudosarcomatous tumor). Arch Esp Urol. 2004; 57: 657-660. Ref.: https://goo.gl/SAK8Zw

2. Khallouk A, Ahallal Y, Tazi MF, Elfatemi $H$, Tazi E, et al. Inflammatory pseudotumor of the kidney: a case report. J Med Case Reports. 2011; 5: 411 Ref.: https://goo.gl/MK4BRj

3. Hafiz MA, Toker C, Sutula M. An atypical fibromyxoid tumor of the prostate. Cancer. 1984; 54: 25002504. Ref.: https://goo.gl/Kakyim

4. Ro JY, El-naggar AK, Amin MB, Sahin AA, Ordonez NG, et al. Pseudosarcomatous fibromyxoid tumor of the urinary bladder and prostate: immunohistochemical, ultrastructural, and flow cytometric analyses of nine cases. 1993; 24: 1203-1210. Ref.: https://goo.gl/Mb5gQJ

5. Matsubara O, Tan-Liu NS, Kenney RM, Mark EJ. Inflammatory pseudotumors of the lung: progression from organizing pneumonia to fibrous histiocytoma or to plasma cell granuloma in 32 cases. Hum Pathol. 1988; 19: 807-814. Ref.: https://goo.gl/Aw9Tyu

6. Toksoz S, Kervancioglu E, Atılgan AO, Güvel S. Pseudosarcomatous fibromyxoid tumor of the prostate revealed on suprapubic prostatectomy. Cent European J Urol. 2012; 65: 98-99. Ref.: https://goo.gl/4jLpzZ

7. Coffin CM, Dehner LP, Meis-Kindblom JM. Inflammatory myofibroblastic tumor, inflammatory fibrosarcoma, and related lesions: an historical review with differential diagnostic considerations. Semin Diagn Pathol. 1998; 15: 102-110. Ref.: https://goo.gl/9qaVFf

8. Coffin CM, Humphrey PA, Dehner LP. Extrapulmonary inflammatory myofibroblastic tumor: a clinical and pathological survey. Semin Diagn Pathol. 1998; 15: 85-101. Ref.: https://goo.gl/7zeoAc

9. Atis G, Gurbuz C, Kiremit MC, Guner B, Zemheri E, et al. Pseudosarcomatous Fibromyxoid Tumor of the Prostate. The Scientific World Journal 2011; 11: 1027-1030. Ref.: https://goo.gl/JL6MN8

10. Jensen JB, Langkilde NC, Lundbeck F, Marcussen N. Pseudosarcomatous Fibromyxoid Tumor of the Prostate. Scand J Urol Nephrol. 2003; 37: 85-87. Ref.: https://goo.gl/X2X4Km

11. Zhang HH, Qi F, Zu XB, Xu L, Liu LF, et al. Recurrence of inflammatory myofibroblastic tumor in bladder secondary to prostate treated with laparoscopic radical cystectomy. Med Sci Monit. 2012; 18: 63-66. Ref.: https://goo.gl/Tgq22m

12. Liu C, Zhao XH, Zhao ZW, Lu P, Jin F, et al. Malignant inflammatory myofibroblastic tumor of the prostate. J Clin Oncol. 2013; 31: e144-e147. Ref.: https://goo.gl/Ww5Jub

13. Montgomery EA, Shuster DD, Burkart AL, Esteban JM, Sgrignol A, et al. Inflammatory Myofibroblastic Tumors of the Urinary Tract: A Clinicopathologic Study of 46 Cases, Including a Malignant Example Inflammatory Fibrosarcoma and a Subset Associated With High-grade Urothelial Carcinoma. Am J Surg Pathol. 2006; 30: 1502-1512. Ref.: https://goo.gl/AqVXSe

14. Antonescu CR, Suurmeijer AJ, Zhang L, Sung YS, Jungbluth AA, et al. Molecular characterization of inflammatory myofibroblastic tumors with frequent ALK and ROS1 gene fusions and rare novel RET rearrangement. Am J Surg Pathol. 2015; 39: 957-967. Ref.: https://goo.gl/uLfc8S

15. Griffin CA, Hawkins AL, Dvorak C, Henkle C, Ellingham T, et al. Recurrent involvement of 2p23 in inflammatory myofibroblastic tumors. Cancer Res. 1999; 59: 2776-2780. Ref.: https://goo.gl/fk3JbV

16. Cantera JE, Alfaro MP, Rafart DC, Zalazar R, Muruzabal MM, et al. Inflammatory myofibroblastic tumours: a pictorial review. Insights Imaging. 2015; 6: 85-96. Ref.: https://goo.gl/e8VgiD

17. Huang WL, Ro JY, Grignon DJ, Swanson D, Ordonez NG, et al. Postoperative spindle cell nodule of the prostate and bladder. J Urol. 1990; 143: 824-826. Ref.: https://goo.gl/eJkBDu

18. Choi E, Williamson SR, Montironi R, Zhang S, Wang M, et al. Inflammatory myofibroblastic tumour of 
the urinary bladder: the role of immunoglobulin $\mathrm{G} 4$ and the comparison of two immunohistochemical antibodies and fluorescence in-situ hybridization for the detection of anaplastic lymphoma kinase alterations. Histopathology. 2015; 67: 20-38. Ref.: https://goo.gl/FDiTmq

19. Iczkowski KA, Shanks JH, Gadaleanu V, Cheng L, Jones EC, et al. Inflammatory pseudotumor and sarcoma of urinary bladder: differential diagnosis and outcome in thirty-eight spindle cell neoplasms. Mod Pathol. 2001; 14: 1043-1051. Ref.: https://goo.gl/gz2uM5

20. Helpap B. Nonepithelial tumor-like lesions of the prostate: a never-ending diagnostic problem. Virchows Arch. 2002; 441: 231-237. Ref.: https://goo.gl/DHBg27

21. Ordoñez NG, Ayala AG, von Eschenbach AC, Mackay B, Hanssen G. Immunoperoxidase localization of prostatic acid phosphatase in prostatic carcinoma with sarcomatoid changes. Urology. 1982; 19 : 210-214. Ref.: https://goo.gl/R5tMNA

22. Wick MR, Young RH, Malvesta R, Beebe DS, Hansen JJ, et al. Prostatic carcinosarcomas. Clinical, histologic, and immunohistochemical data on two cases, with a review of the literature. Am J Clin Pathol. 1989; 92: 131-139. Ref.: https://goo.gl/7hbyMA

23. Verhest A, Jortay A. Carcinosarcoma. Case of malpighian epithelioma of the pyriform sinus with pseudosarcomatous reaction of the stroma. Bull Cancer. 1968; 55: 429-437. Ref.: https://goo.gl/DkYZJw

24. Kuramoto T, Kohjimoto $\mathrm{Y}$, Mori T, Kikkawa K, Senzaki H, et al. Inflammatory pseudotumor of the prostate: a case report. Hinyokika Kiyo. 2005; 51: 767-770. Ref.: https://goo.gl/8Fdpyd 